\title{
Fuzzy logic in automation for interpretation of adaptability and stability in plant breeding studies
}

\author{
Anna Regina Tiago Carneiro ${ }^{\oplus}$, Demerson Arruda Sanglard ${ }^{\oplus}$, Alcinei Mistico Azevedo ${ }^{1 *} \odot$, Thiago Lívio Pessoa Oliveira de Souza ${ }^{2}$, \\ Helton Santos Pereira2 ${ }^{\circledR}$, Leonardo Cunha Melo2 ${ }^{2}$
}

'Universidade Federal de Minas Gerais/Instituto de Ciências Agrárias, Av. Universitária, 1000 - 39404-006 - Montes Claros, MG - Brasil.

Embrapa Arroz \& Feijão, Rod. GO-462, km 12 - 75375-000

- Santo Antônio de Goiás, GO - Brasil.

*Corresponding author <alcineimistico@hotmail.com>

Edited by: Paulo Cesar Sentelhas

Received June 22, 2017

Accepted October 29, 2017
ABSTRACT: The methods of Annicchiarico (1992) and Cruz et al. (1989) are widely used in phenotypic adaptability and stability analyses in plant breeding. In spite of the importance of these methodologies, their parameters are difficult to interpret. The aim of this research was to develop fuzzy controllers to automate the decision-making process employed by adaptability and stability studies following the methods adopted by Annicchiarico (1992) and Cruz et al. (1989) and check their efficiency using experimental data from common bean cultivars. Fuzzy controllers have been developed based on the Mamdani inference system proposed by these two methods of adaptability and stability studies. For the first fuzzy controller parameters were considered favorable environments and the recommendation index for unfavorable environments obtained by Annicchiarico's method (1992). For the second controller the parameters considered were the general mean $\left(\beta_{0}\right)$, coefficient of regression of unfavorable environments $\left(\beta_{1}\right)$ and coefficient of favorable environments $\left(\beta_{1 i}+\beta_{2 i}\right)$ and the coefficient of determination of the method of Cruz et al. (1989). To check the performance of these drivers yield data from field trials on 18 common bean cultivars grown in 11 environments were used. The controllers were developed from established routines in the R software and, using the inference system based on the methods proposed by Annicchiarico (1992) and Cruz et al. (1989), classified the 18 genotypes appropriately in accordance with the criteria for each method. Thus, the methods used are effective, and are prescribed for decision-making automation in yield adaptability and stability studies pertaining to recommendation of cultivars.

Keywords: common bean, genotype by environment interaction, crop breeding, computational intelligence

\section{Introduction}

Phenotypic adaptability and stability analyses are tools which provide detailed information on cultivar behavior which help in the selection of genotypes that are less influenced by the interaction between genotypes and environments $(G \times E)$ (Almeida Filho et al., 2014). Two methods have been widely used to study adaptability and stability, namely, those advanced by Annicchiarico (1992) and Cruz et al. (1989).

In spite of the importance of these methodologies, their parameters are difficult to interpret, especially when a considerable number of genotypes are involved, which makes selection work slow and decisions by breeders difficult to make. Therefore, the use of tools and strategies that can help make assertive decisions are indispensable to the success of breeding programs (Carneiro et al, 2018). In this context fuzzy logic invites consideration.

Fuzzy logic translates vague and confusing verbal expressions common in human communication into numerical values, as well as allowing for the conversion of human experience into a computer decodable language (Simões and Shaw, 2011). Because of these properties and the ability to perform inferences, it has found significant applications in automation in several areas of knowledge, such as the risk of weed infestation in crops (Bressan et al., 2008), the determination of soil yield as a function of its physical and chemical characteristics (Duru et al., 2010), the support of nitrogen fertilization (Papadopoulos et al., 2011), the management of wheat crops (Islam et al., 2012), for Solum depth spatial prediction (Menezes et al., 2014), and irrigation and conservation in agriculture (Giusti and Marsili-Libelli, 2015) among others.

In the genetic improvement of plants, the fuzzy logic was applied by Carneiro et. al (2018) to the classification of cultivars regarding the adaptability and stability following the methods of Eberhart and Russell (1966). This author demonstrated that fuzzy logic had the capacity to interpret the parameters of these methods and, consequently, to automate the decisions that would be made by optimists.

Thus, the aim was to develop fuzzy controllers to automate decision-making in adaptability and stability studies in accordance with the methods of Annicchiarico (1992) and Cruz et al. (1989) and to verify their efficiency using, as an example, yield data from grains obtained from trials on common bean cultivars.

\section{Materials and Methods}

\section{Methods of adaptability and stability}

The methods of Annicchiarico (1992) and Cruz et al. (1989) were adopted to study the phenotypic 
adaptability and stability of common bean cultivars. The Annicchiarico method (1992) is based on the recommendation index $\left(\omega_{i|g|}\right)$, in which stability and, also, genotypic adaptability is given by: $\omega_{i(g)}=\mu_{\mathrm{i}|g|}-Z_{(1-\alpha)}$ $\sigma_{z i}$ in which $\omega_{i|g|}$ is the recommendation index; $\mu_{i(g)}$ the average percentage of genotypes $i_{i} \mathrm{Z}_{(1-\alpha)}$ the percentage of the standard normal distribution function, and $\sigma_{z i}$ the standard deviation of the values $Z_{i j}$, associated with the ith genotype.

The Cruz et al. (1989) method is based on bisegmented regression analysis, using the following statistical model: $Y_{i j}=\beta_{0 i}+\beta_{1 i} I_{j}+\beta_{2 i} T\left(I_{j}\right)+\delta_{i j}+\varepsilon_{i j}$ in which $Y_{i j}$ is the average of the $\mathrm{i}$-th genotype in the jth environment; $\beta_{0 i}$ the average of the $i$-th genotype; $\beta_{1 i}$ the linear regression coefficient; $I_{j}$ the encoded environmental in$\operatorname{dex}\left(\sum_{j}^{i} I_{j}=0\right)$ and where: $I_{j} \leq 0$, then $T\left(I_{j}\right)=0$; however, if $I_{j}>0$, then $T\left(I_{j}\right)=I_{j_{-}} I_{+}$, where: $I_{+}$is the average of the indexes $\left(I_{j}\right)$ positives.

In order to bring automation to the decision making process, two fuzzy controllers were developed, one for the Annicchiarico (1992) and a second for the Cruz et al. (1989) method. The controllers were developed based on routines established in the $\mathrm{R}$ software ( $\mathrm{R}$ Development Core Team, 2010), and all the algorithms used in this study have been presented by Carneiro et al. (2018).

\section{Development of the fuzzy methodology for the Annicchiarico method}

For the Annicchiarico method (1992), the fuzzy controller based on the fuzzy inference system proposed by Mamdani (Mamdani and Assilian, 1975) was developed. The input fuzzy linguistic variables used were the recommendation index parameters for favorable environments $\left|\omega_{f}\right\rangle$ and the recommendation index parameters for unfavorable environments $\left(\omega_{d}\right)$. Fuzzy sets were generated for each variable by means of pertinence functions that allowed, through the "fuzzification" process, for the classification of each cultivar evaluated for these parameters. The values of $\left(\omega_{f}\right)$ and $\omega_{d}$ were allocated to the fuzzy sets "Low" and "High", by means of the form-fitting functions of $\mathrm{Z}$ and S-shape, respectively (Figure 1).

An output linguistic fuzzy variable, called "Mamdani Behavior", was generated. The values of this variable were allocated in four fuzzy sets based on performance regarding the adaptability and stability of the genotypes evaluated: General (GE); Favorable environment (FE); Unfavorable Environment (UE) and Not Indicated (NI). The rules used in the developed fuzzy controllers were based on the interpretation of the parameters of the method of Annicchiarico (1992). Table 1 presents the rules applied to the controllers developed based on the Annicchiarico method (1992).

\section{Development of the fuzzy methodology for the Cruz et al. method}

For the Cruz et al. (1989) method, the fuzzy controller was also developed based on the fuzzy
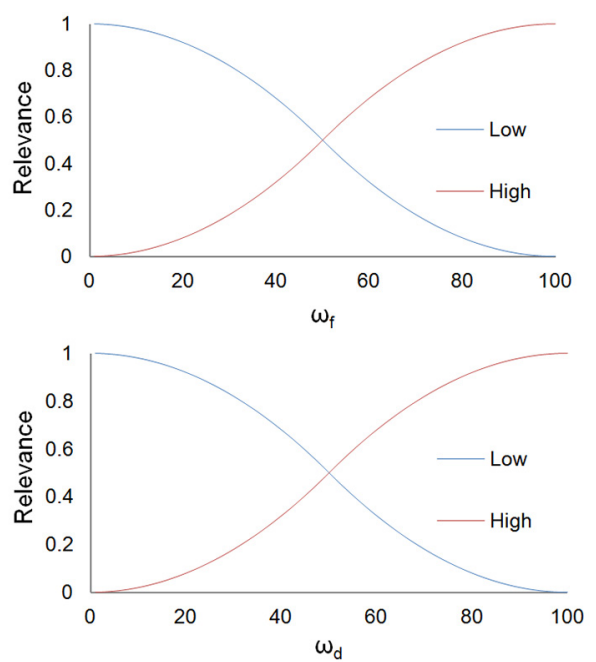

Figure 1 - Assigned membership functions for linguistic variables $\omega_{f}$ and $\omega_{d}$.

Table 1 - Linguistic fuzzy rules implemented in behavioral fuzzy controllers regarding the adaptability and stability of the Annicchiarico method (1992).

\begin{tabular}{|c|c|c|}
\hline \multicolumn{2}{|c|}{ Inputs } & \multirow{2}{*}{$\begin{array}{c}\text { Output } \\
\text { Mamdani behavior }\end{array}$} \\
\hline$\omega_{d}$ & $\omega_{f}$ & \\
\hline High & High & General \\
\hline Low & High & Favorable environment \\
\hline High & Low & Unfavorable environment \\
\hline Low & Low & Not indicated \\
\hline
\end{tabular}
index for unfavorable environments.

inference system proposed by Mamdani (Mamdani and Assilian, 1975). The fuzzy linguistic input variables used were the general mean parameters $\left(\beta_{0}\right)$, the coefficient of regression of unfavorable environments $\left(\beta_{1}\right)$, the coefficient of favorable environments $\left(\beta_{1 i}+\beta_{2 i}\right)$ and the coefficient of determination $\left(\mathrm{R}^{2}\right)$. Fuzzy sets were generated for each variable by means of pertinence functions that allowed, by means of the "fuzzification" process, for the classification of each cultivar evaluated based on the criteria of adaptability and stability.

The general averages of cultivars $\left(\beta_{0}\right)$ were standardized on a scale of zero to 100 . Standardization was based on the normal distribution of the data, the overall mean value $(\mu)$ and the standard deviation $(\sigma)$ of these data. The values associated with $\mu-3 \sigma$ were assigned the value zero and the values associated with $\mu$ $+3 \sigma$ the value of 100 (Figure 2A).

The values of the regression coefficients of unfavorable environments $\left(\beta_{1}\right)$ and of the coefficient of favorable environments $\left(\beta_{1}+\beta_{2}\right)$ were allocated to the sets "Less than one", "Same as one" and "Greater than one", by means of the form membership functions of Z ("zmf"), form of " $\pi$ " ("pimf") and form of S ("smf"), respectively. In this classification, the cultivars that 
were considered had relevance above $50 \%$, in the set "Equal to one", and presented values of $\beta_{1}$ and $\beta_{1 i}+\beta_{2 \mathrm{i}}$ statistically equal to one according to Student's $t$ test. The values of the $\beta_{1}$ and $\beta_{1 i}+\beta_{2 i}$ originals of each genotype, when submitted to the controller, were standardized. This standardization was based on a confidence interval with $95 \%$ probability, and a t-distribution, considering the null hypothesis whereby $\beta_{1}$ and $\beta_{1 t}+\beta_{2 i}$ are equal to one. At the lower limit of the confidence interval, -2 was assigned and the upper limit was assigned the value four (Figure $2 \mathrm{~B}$ and $\mathrm{C}$ ). The values of the coefficients of determination $\left(\mathrm{R}^{2}\right)$ were allocated to the fuzzy sets "Low" and "High", by means of the form membership functions of $\mathrm{Z}$ and the form of $\mathrm{S}$, respectively (Figure $2 \mathrm{D}$ ).

An output linguistic fuzzy variable called "Mamdani Behavior" was generated. The values of this variable were allocated to eight fuzzy sets based on performance in terms of adaptability and stability of genotypes: Average adaptability to favorable environment (AFE), Maximum adaptability to favorable environment (MaxFE), Not adapted (NA), Average general adaptability (AGA), Maximum general adaptability (MaxGA), Maximum adaptability to unfavorable environments (MaxUE), Low stability (LS) and Low yield (LY). Table 2 presents the rules used in fuzzy controllers developed based on the interpretation of the parameters of the method proposed by Cruz et al. (1989).

\section{Field trials with common bean cultivars}

In order to test the efficiency of developed fuzzy controllers, real grain yield data were obtained from field evaluation trials on 18 cultivars from the commercial group "Carioca" (Alba, BRS Cometa, BRS Estilo, BRS Horizonte, BRSMG Majestoso, BRSMG Pioneiro, BRSMG Talismã, BRS Pontal, BRS Requinte, Campeão 2, Guará, IAC Tybatã, IPR Colibri, IPR Juriti, IPR Saracura, Magnífico, Pérola and Rubi).
The trials were conducted at 11 locations and in the following years: Ponta Grossa, in the state of Parana, longitude $50^{\circ} 09^{\prime} 43^{\prime \prime} \mathrm{O}$, latitude $25^{\circ} 05^{\prime} 42^{\prime \prime} \mathrm{S}$, and elevation $956 \mathrm{~m}$, in the 2006, 2008 and 2010 growing seasons and in the 2007 and 2010 off seasons; in Santo Antônio of Goiás, in the state of Goiás, longitude $49^{\circ} 18^{\prime} 32^{\prime \prime} \mathrm{O}$, latitude $16^{\circ} 29^{\prime} 8^{\prime \prime} \mathrm{S}$, and elevation $823 \mathrm{~m}$, in the 2006, 2008, and 2010 winter seasons and in Uberlândia, in the state of Minas Gerais, longitude $48^{\circ} 16^{\prime} 38^{\prime \prime} \mathrm{O}$ latitude $18^{\circ} 55^{\prime} 07^{\prime \prime} \mathrm{S}$, and elevation $780 \mathrm{~m}$, in the 2007 and 2008 winter seasons and in the 2008 off season. The experimental design was a randomized block design, with three replications. The experimental plots consisted of four lines, $4.0 \mathrm{~m}$ in length, spaced $0.5 \mathrm{~m}$ apart. The yield data were col-

Table 2 - Language fuzzy rules implemented in the Mamdani fuzzy controller based on the adaptability and stability of the Cruz et al. method (1989).

\begin{tabular}{|c|c|c|c|c|}
\hline \multicolumn{4}{|c|}{ Inputs } & \multirow{2}{*}{$\begin{array}{c}\text { Output } \\
\text { Mamdani behavior }\end{array}$} \\
\hline Average & $\beta_{1}$ & $\beta_{1}+\beta_{2}$ & $\mathrm{R}^{2}$ & \\
\hline High & Equal to 1 & Equal to 1 & High & AFE \\
\hline High & Equal to 1 & Higher than 1 & High & MaxFE \\
\hline High & Equal to 1 & Lower than 1 & High & NA \\
\hline High & Higher than 1 & Equal to 1 & High & AFE \\
\hline High & Higher than 1 & Higher than 1 & High & MaxFE \\
\hline High & Higher than 1 & Lower than 1 & High & NA \\
\hline High & Lower than 1 & Equal to 1 & High & AGA \\
\hline High & Lower than 1 & Higher than 1 & High & MaxGA \\
\hline \multirow[t]{2}{*}{ High } & Lower than 1 & Lower than 1 & High & MaxUE \\
\hline & Other combina & ions & Low & LY \\
\hline
\end{tabular}

Low Other combinations - OY

AFE = Average adaptability to favorable environments; MaxFE = Maximum adaptability to favorable environments; $N A=$ Not adapted; $A G A=$ Average general adaptability; MaxGA = Maximum overall adaptability; MaxUE = Maximum adaptability to unfavorable environments; LS = Low stability; and $\mathrm{LY}=$ Low yield
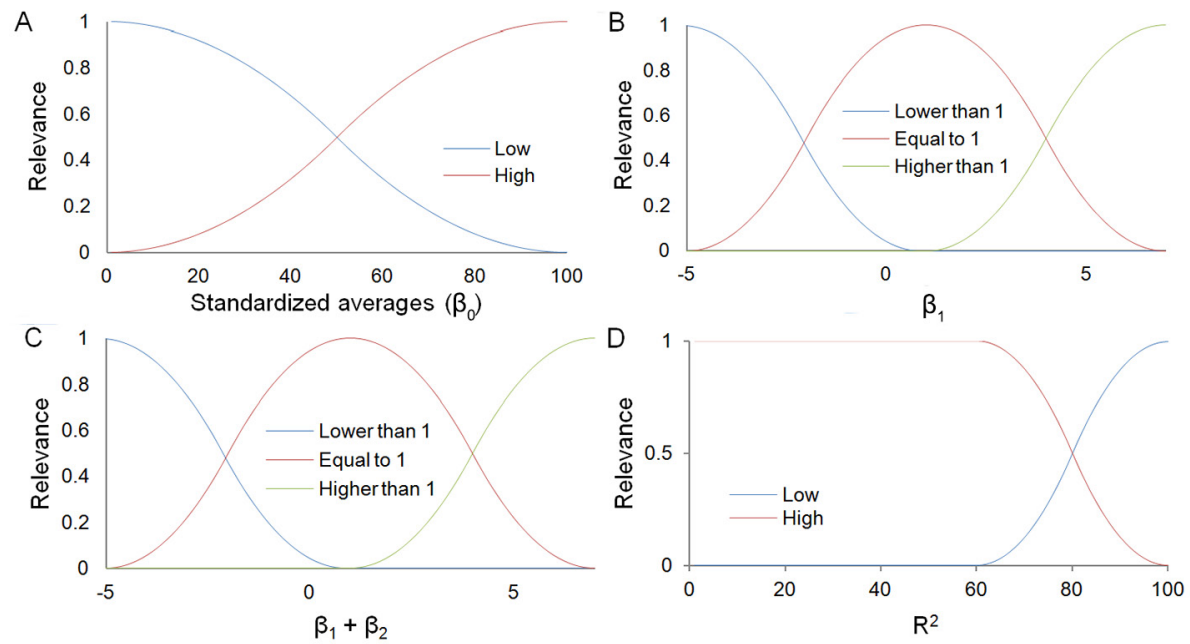

Figure 2 - A) Assigned membership functions for the "standardized average" $\left(\beta_{0}\right)$. B) linguistic variables $\left(\beta_{1}\right)$. C) standardized coefficient for favorable environments $\left(\beta_{1}+\beta_{2}\right)$. D) coefficient of determination $\left(R^{2}\right)$. 
lected from the two central lines of each plot, whose yield was measured and converted into $\mathrm{kg} \mathrm{ha}^{-1}$, with $13 \%$ of grain moisture.

The experimental data were submitted to analysis of individual variance, the residues being found to be homogeneous, which ensured the viability of the joint analysis. After analyzing the significance of the interaction of genotypes by environments using the $\mathrm{F}$ test at $5 \%$, analyses of adaptability and stability were performed in accordance with the methods of Annicchiarico (1992) and Cruz et al. (1989). Subsequently, the parameters obtained by these methods were submitted to the fuzzy controllers created in order to determine behavior and establish the recommendation of these cultivars.

\section{Results}

Table 3 presents the estimates of pertinence through the fuzzy controller based on the Annicchiarico method (1992), which indicate in which of the four groups each of the genotypes was to be classified by the fuzzy controller. Thus, the BRS Pontal cultivar was classified as general behavior (GB). This classification is correct, since this genotype presented high index of recommendation readings both for favorable environments $\left(\omega_{f}\right)$ and highly unfavorable $\left(\omega_{d}\right)$. The cultivars BRS Estilo, Campeão 2 and IPR Juriti were classified as indicated for favorable environments (FE). This is due to the recommendation index for favorable environments being $\left(\omega_{f}\right)$ High (average yield above the general average, which is $1,952 \mathrm{~kg} \mathrm{ha}^{-1}$ in favorable environments).
Alba cultivars BRS Cometa, BRS Horizonte, BRSMG Majestoso, BRSMG Pioneiro, BRSMG Talismã, BRS Requinte, Guará, IAC Tybatã, IPR Colibri, IPR Saracura, Magnífico, Perola and Rubi had already been classified as non-indicated (NI). This can be justified by their low recommendation index, both for favorable environments $\left(\omega_{f}\right)$ and for unfavorable environments $\left(\omega_{d}\right)$. However, it should be noted that the Pearl was already the most widely cultivated bean cultivar in the country, showing good comparative performance in different growing regions and sowing times, considering real farming conditions.

The largest estimates of pertinence presented (Table 4) indicate in which of the eight groups each of the genotypes should be classified by the fuzzy controller. Based on the Cruz et al. (1989) method, none of the cultivars presented behavior indicated for favorable and unfavorable environments (MaxFE and MaxUE). This agrees with the estimated parameters, since no genotype showed high yield $\left(\beta_{0}\right)$; low sensitivity to adverse conditions in unfavorable environments $\left(\beta_{1 i}<1\right)$; responsiveness to environmental improvement $\left(\beta_{1 i}+\beta_{2 \mathrm{i}}>1\right)$ and $\mathrm{a}$ high coefficient of determination $\left(\mathrm{R}^{2}>0.80\right)$. Although no cultivar was indicated for both favorable and unfavorable environments (MaxFE and MaxUE), genotypes BRS Horizonte, BRS Requinte, IPR Colibri and IPR Saracura came closest to this classification, due to the greater relevance to these groups.

Cultivars BRS Estilo, BRS Pontal, Campeão 2, IAC Tybatã and IPR Juriti were classified by the fuzzy controllers as having medium adaptability to favorable environments (AFE). This classification is correct, and can be justified by means of the high readings in the

Table 3 - Recommendation index estimates for favorable environments $\left(\omega_{f}\right)$, unfavorable $\left(\omega_{d}\right)$ and classification by the fuzzy controller of the behavior of 18 common bean cultivars, in 11 environments, based on the Annicchiarico method (1992).

\begin{tabular}{|c|c|c|c|c|c|c|c|}
\hline \multirow{2}{*}{ Cultivars } & \multicolumn{2}{|c|}{ Index of recommendation } & \multicolumn{4}{|c|}{ Behavior in pertinences } & \multirow{2}{*}{ Classification } \\
\hline & $\omega_{f}$ & $\omega_{d}$ & GB & $\mathrm{FE}$ & UE & $\mathrm{NI}$ & \\
\hline Alba & 81.77 & 74.63 & 28 & 33 & 28 & 67 & $\mathrm{NI}$ \\
\hline BRS Cometa & 91.91 & 85.75 & 37 & 42 & 37 & 58 & $\mathrm{NI}$ \\
\hline BRS Estilo & 107.40 & 97.69 & 48 & 52 & 43 & 43 & $\mathrm{FE}$ \\
\hline BRS Horizonte & 82.98 & 75.08 & 28 & 34 & 28 & 66 & $\mathrm{NI}$ \\
\hline BRSMG Majestoso & 89.72 & 84.73 & 36 & 40 & 36 & 60 & $\mathrm{NI}$ \\
\hline BRSMG Talismã & 97.34 & 86.54 & 37 & 47 & 37 & 53 & $\mathrm{NI}$ \\
\hline BRS Pontal & 109.19 & 101.52 & 52 & 48 & 41 & 41 & GB \\
\hline BRS Requinte & 75.78 & 97.26 & 29 & 29 & 47 & 53 & $\mathrm{NI}$ \\
\hline Campeão 2 & 101.33 & 99.63 & 49 & 50 & 49 & 49 & FE \\
\hline Guará & 90.19 & 91.96 & 41 & 41 & 42 & 58 & $\mathrm{NI}$ \\
\hline IAC Tybatã & 98.99 & 93.49 & 44 & 49 & 44 & 51 & $\mathrm{NI}$ \\
\hline IPR Juriti & 103.15 & 95.63 & 46 & 53 & 46 & 47 & $\mathrm{FE}$ \\
\hline IPR Saracura & 90.56 & 92.29 & 41 & 41 & 43 & 57 & $\mathrm{NI}$ \\
\hline Magnífico & 77.93 & 82.30 & 30 & 30 & 34 & 66 & $\mathrm{NI}$ \\
\hline Pérola & 99.81 & 80.09 & 32 & 49 & 32 & 50 & $\mathrm{NI}$ \\
\hline Rubi & 89.08 & 72.87 & 27 & 40 & 27 & 60 & $\mathrm{NI}$ \\
\hline
\end{tabular}

Classifications: General behavior (GB), Favorable environment (FE), Unfavorable environment (UE) and Not indicated (NI). 
Table 4 - Estimates of the general average $\left(\beta_{0}\right)$, linear response to unfavorable environments $\left(\beta_{1}\right)$, linear response to favorable environments $\left(\beta_{1 i}\right.$ $\left.+\beta_{2 i}\right)$, determination coefficient $\left(R^{2}\right)$ and classification by the fuzzy controller of the behavior of 18 common bean cultivars, based on the Cruz et al. (1989) method.

\begin{tabular}{|c|c|c|c|c|c|c|c|c|c|c|c|c|c|}
\hline \multirow{2}{*}{ Cultivars } & \multicolumn{4}{|c|}{ Parameters } & \multicolumn{8}{|c|}{ Behavior in Pertinences } & \multirow{2}{*}{ Group } \\
\hline & $\beta_{0}$ & $\beta_{1}$ & $\beta_{1 i}+\beta_{2 i}$ & $\mathrm{R}^{2}$ & AFE & MaxFE & NA & AGA & MaxGA & MaxUE & LS & LY & \\
\hline Alba & 1.757 & $0.99^{\text {ns }}$ & $1.20^{\mathrm{ns}}$ & 0.89 & 21 & 21 & 0 & 0 & 0 & 0 & 16 & 77 & $L Y$ \\
\hline BRS Cometa & 1.811 & $1.02^{\mathrm{ns}}$ & $0.85^{\mathrm{ns}}$ & 0.96 & 31 & 0 & 12 & 0 & 0 & 0 & 2 & 69 & LY \\
\hline BRS Estilo & 2.103 & $1.11^{\mathrm{ns}}$ & $1.28^{\mathrm{ns}}$ & 0.96 & 57 & 43 & 0 & 0 & 0 & 0 & 2 & 13 & AFE \\
\hline BRS Horizonte & 1.752 & $0.81^{*}$ & $0.98^{\mathrm{ns}}$ & 0.83 & 21 & 0 & 0 & 21 & 0 & 0 & 21 & 64 & $\mathrm{LY}$ \\
\hline BRSMG Majestoso & 1.881 & $1.00^{\text {ns }}$ & $0.99^{\text {ns }}$ & 0.89 & 45 & 0 & 0 & 0 & 0 & 0 & 15 & 55 & LY \\
\hline BRSMG Pioneiro & 2.016 & $1.05^{\mathrm{ns}}$ & $0.55^{\star *}$ & 0.88 & 13 & 0 & 74 & 0 & 0 & 0 & 17 & 26 & NA \\
\hline BRSMG Talismã & 1.851 & $1.07^{\mathrm{ns}}$ & $0.96^{\text {ns }}$ & 0.97 & 39 & 0 & 1 & 0 & 0 & 0 & 1 & 61 & LY \\
\hline BRS Pontal & 2.113 & $1.11^{\mathrm{ns}}$ & $1.12^{\mathrm{ns}}$ & 0.97 & 71 & 8 & 0 & 0 & 0 & 0 & 1 & 12 & AFE \\
\hline BRS Requinte & 1.835 & $0.83^{*}$ & $1.14^{\mathrm{ns}}$ & 0.79 & 34 & 10 & 0 & 35 & 10 & 0 & 35 & 52 & $\mathrm{LY}$ \\
\hline Campeão 2 & 2.079 & $1.15^{\mathrm{ns}}$ & $1.28^{\text {ns }}$ & 0.94 & 51 & 44 & 0 & 0 & 0 & 0 & 4 & 16 & AFE \\
\hline Guará & 2.012 & $1.11^{\mathrm{ns}}$ & $0.43^{* *}$ & 0.76 & 0 & 0 & 33 & 0 & 0 & 0 & 67 & 27 & LS \\
\hline IAC Tybatã & 1.934 & $1.03^{\mathrm{ns}}$ & $1.20^{\mathrm{ns}}$ & 0.98 & 58 & 23 & 0 & 0 & 0 & 0 & 1 & 42 & AFE \\
\hline IPR Colibri & 1.719 & $0.78^{* *}$ & $111^{\mathrm{ns}}$ & 0.88 & 13 & 7 & 0 & 16 & 7 & 0 & 16 & 81 & LY \\
\hline IPR Juriti & 2.017 & $1.07^{\mathrm{ns}}$ & $0.80^{\text {ns }}$ & 0.98 & 74 & 0 & 23 & 0 & 0 & 0 & 0 & 26 & AFE \\
\hline IPR Saracura & 1.875 & $0.83^{*}$ & $0.78^{\text {ns }}$ & 0.94 & 34 & 0 & 26 & 44 & 0 & 26 & 4 & 56 & $\mathrm{LY}$ \\
\hline Magnífico & 1.640 & $0.74^{* *}$ & $0.91^{\mathrm{ns}}$ & 0.91 & 2 & 0 & 2 & 7 & 0 & 5 & 7 & 91 & LY \\
\hline Pérola & 1.970 & $1.21^{\star *}$ & $1.47^{\star *}$ & 0.97 & 10 & 65 & 0 & 0 & 0 & 0 & 1 & 35 & MaxFE \\
\hline Rubi & 1.859 & $1.09^{\text {ns }}$ & $0.94^{\text {ns }}$ & 0.89 & 40 & 0 & 2 & 0 & 0 & 0 & 16 & 60 & LY \\
\hline
\end{tabular}

Coefficients followed by ns, ${ }^{*}$ and ${ }^{* *}$ are, respectively: not significant at the $5 \%$ level, significant at the $5 \%$ level and significant at the $1 \%$ probability level by the t test when considering as a null hypothesis that $\beta_{1}=1$, and $\beta_{1 i}+\beta_{2 i}=1$. AFE = Average adaptability to favorable environments; MaxFE = Maximum adaptability to favorable environments; $\mathrm{NA}=$ Not adapted; $\mathrm{AGA}=$ Average general adaptability; MaxGA = Maximum general adaptability; MaxUE = Maximum adaptability to unfavorable environments; $L S=$ Low stability; and LY = Low yield.

genotypes (above the average overall by $1.952 \mathrm{~kg} \mathrm{ha}^{-1}$ ); $\beta_{1} \geq 1 ; \beta_{1}+\beta_{2}=1$ and high determination coefficient $\mathrm{R}^{2}>80 \%$. Cultivar Pérola had already been classified as having maximum adaptability to favorable environments (MaxFE), which is justified by a $\beta_{0}$ higher than the general average of $1.952 \mathrm{~kg} \mathrm{ha}^{-1} ; \beta_{1} \geq 1 ; \beta_{1}+\beta_{2}>1$ and $\mathrm{R}^{2}$ high (above $80 \%$ ).

Cultivar Guará was classified as low stability (LS). This is a consequence of $\beta_{1}$ being greater than one, indicating that this cultivar is highly sensitive to the adverse conditions of unfavorable environments and $\mathrm{R}^{2}$ above $80 \%$. Cultivars Alba, BRS Cometa, BRS Horizonte, BRSMG Majestoso, BRSMG Talismã, BRS Requinte, IPR Colibri, IPR Saracura, Magnífico and Rubi were considered to be low yield, with estimates lower than $1.952 \mathrm{~kg} \mathrm{ha}^{-1}$. Finally, cultivar BRSMG Pioneiro was considered not appropriate (NA). This can be justified by the $\beta_{1}$ being slightly higher than one and $\beta_{1}+$ $\beta_{2}$ lower than one, indicating that this cultivar presents high sensitivity to adverse conditions in unfavorable environments (Table 3).

The fuzzy controllers based on the methods of Annicchiarico (1992) and Cruz et al. (1989) classified the 18 cultivars adequately and in accordance with the established fuzzy rules and parameters of each method.

\section{Discussion}

The studies of phenotypic adaptability and stability are important to breeding programs. They allow for the identification of genotypes with the capacity to take advantage of the stimulus of the environment, with predictable behavior patterns which respond to the environmental variations, be they under specific or broad conditions (Gauch, 1992), or even those ampler and general genotypes with little sensitivity to environmental variation. However, when a substantial number of genotypes are evaluated, the interpretation of the parameters of adaptability and stability becomes laborious, requiring considerable time on the part of the breeder and can lead to misunderstandings. In this case, automation of genotype classification by fuzzy logic is a viable option (Carneiro et al., 2018).

Among the various methods of adaptability and stability are those of Annicchiarico (1992) and Cruz et al. (1989). The Annicchiarico method (1992) takes as a reference the average of each of the environments, being calculated from the index of confidence or recommendation, which represents the chance of cultivar $i$ to present a phenotypic performance superior to the general average for favorable environments $\left(\omega_{f}\right)$ and unfavorable $\left(\omega_{d}\right)$ environments. On the other hand, the Cruz et al. method (1989), is based on estimates of parameters obtained in bissegmented regression $\left(\beta_{0}\right.$, $\beta_{1 i}+\beta_{2 i}$, and $\mathrm{R}^{2}$ ), and takes into consideration how genotypes behave differently in both favorable (with negative values of the environmental index) and unfavorable environments (with positive values of the environmental index). 
For the fuzzy controller adapted for both the Annicchiarico (1992) and the Cruz Torres and Vencovsky approach (1989), it was found that the classification of genotype stability and adaptability had been made correctly, according to the traditional interpretation of estimated parameters. The same was verified by Carneiro et al. (2018), when using fuzzy controllers in genotype classification for adaptability and stability following the methods of Eberhart and Russell (1966) and Lin and Binns (1988) using grain yield data from experiments with bean genotypes evaluated in nine environments. The correct classification by the fuzzy controllers is due to the composition of the input and output linguistic variables, allowing for the operator's experience to be codified in rules, enabling the computer to interpret and provide accurate and useful information for decision making (Simões and Shaw, 2011). That is, its efficiency is due to its powerful ability to model complex human reasoning (Türksen, 2007). This ability makes fuzzy logic superior to other more classical statistical methodologies in decision making (Blanco-Fernandez et al., 2013, 2014; Piterbarg, 2011; Viertl, 2011), even though there are uncertainties arising from the lack of definition of limits in the interpretation of the components (parameters) studied (Qin et al., 2007).

An additional and important item of information in the use of the fuzzy controllers is that in addition to classifying the genotype in a group, it also establishes pertinent parameters for the composition of genotype groups. This additional information can be justified, according to Kuo et al. (2009), by the systematization of imprecise knowledge. For genetic improvement, this is very important as if there are no genotypes with a classification of interest, one can use genotypes that are more pertinent to the desired group, such as the selection of parents in breeding programs and the recommendation of cultivars more suited to a given growing condition.

Therefore, fuzzy controllers based on the Annicchiarico (1992) and Cruz et al. (1989) methods have been shown to be useful and efficient as aids to the decision-making automation process in the recommendation of cultivars, according to established fuzzy rules. Consequently, this technique becomes a major ally of breeding programs because of its simplicity and automation capacity, especially when a large number of genotypes are evaluated.

\section{Conclusions}

The fuzzy controllers developed allowed for the correct classification of common bean cultivars according to the traditional interpretation of the parameters of adaptability and stability for the Annicchiarico (1992) and Cruz et al. (1989) methods.

The methods used were efficient in the automation of decision making in the recommendation of cultivars for studies of phenotypic adaptability and stability.

\section{Acknowledgments}

To the Coordenação de Aperfeiçoamento de Pessoal de Nivel Superior (CAPES) for financial support. To the "Embrapa Arroz e Feijão" for the concession of the data. T.L.P.O. Souza, H.S. Pereira and L.C. Melo are supported by CNPq, the Brazilian Council for Scientific and Technological Development.

\section{Authors' Contributions}

Conceptualization: Carneiro, A.R.T., Azevedo, A.M. Data acquisition: Souza, T.L.P.O., Pereira, H.S., Melo, L.C. Data analysis: Azevedo, A.M. Design of Methodology: Azevedo, A.M. Writing and editing: Carneiro, A.R.T., Sanglard, D.A., Azevedo, A.M., Souza, T.L.P.O., Pereira, H.S., Melo, L.C.

\section{References}

Annicchiarico, P. 1992. Cultivar adaptation and recommendation from alfafa trials in northern Italy. Journal of Genetics and Breeding 46: 269-278.

Almeida Filho, J.E.; Tardin, F.D.; Resende, M.D.V.; Silva, F.F.; Granato, I.S.C.; Menezes, C.B. 2014. Genetic evaluation of grain sorghum hybrids in Brazilian environments using the REML/BLUP procedure. Scientia Agricola 71: 146-150.

Blanco-Fernández, A.; Casals, M.R.; Colubi, A.; Corral, N.; Gárcia-Bárzana, M.; Gil, M.A.; González-Rodrígues, G.; López, M.T.; Lubiano, M.A.; Montenegro, M.; Ramos-Guajardo, A.B.; La Rosa de Sá, S.; Sinova, B. 2013. Random fuzzy sets: a mathematical tool to develop statistical fuzzy data analysis. Iranian Journal of fuzzy Systems 10: 1-28.

Blanco-Fernández, A.; Casals, M.R.; Colubi, A.; Corral, N.; García-Bárzana, M.; Gil, M.A.; González-Rodríguez, G.; López, M.T.; Lubiano, M.A.; Montenegro, M.; Ramos-Guajardo, A.B.; La Rosa de Sá, S.; Sinova, B. 2014. A distance-based statistical analysis of fuzzy number-valued data. International Journal of Approximate Reasoning 55: 1487-1501.

Bressan, G.M.; Koenigkan, L.V.; Oliveira, V.A.; Cruvinel, P.E.; Karam, D. 2008. A classification methodology for the risk of weed infestation using fuzzy logic. Weed Research 48: 470479.

Carneiro, V.Q.; Prado, A.L.; Cruz, C.D.; Carneiro, P.C.S.; Nascimento, M.; Carneiro, J.E.S. 2018. Fuzzy control systems for decision-making in cultivars recommendation. Acta Scientiarum. Agronomy 40: 1-8 .

Cruz, C.D.; Torres, R.A.; Vencovsky, R. 1989. An alternative approach to the stability analysis proposed by Silva and Barreto. Revista Brasileira de Genética 12: 567-580.

Duru, N.; Dökmen, F.; Canbay, M.M.; Kurtuluş, C. 2010. Soil productivity analysis based on a fuzzy logic system. Journal of the Science of Food and Agriculture 90: 2220-2227.

Eberhart, S.A.; Russell, W.A. 1966. Stability parameters for comparing varieties. Crop Science 6: 36-40.

Gauch, H.G. 1992. Statistical Analysis of Regional Yield Trials: AMMI Analysis of Factorial Designs. Elsevier, Amsterdam, The Netherlands. 
Giusti, E.; Marsili-Libelli, S. 2015. A fuzzy decision support system for irrigation and water conservation in agriculture. Environmental Modelling \& Software 63: 73-86.

Islam, S.; Kundu, S.; Shoran, J.; Sabir, N.; Sharma, K.; Farooqi, S.; Singh, R.; Agarwal, H.O.; Chaturvedi, K.K.; Sharma, R.K.; Sharma, A.K. 2012. Selection of wheat (Triticum aestivum) variety through expert system. Indian Journal of Agricultural Sciences 82: 39-43.

Kuo, T.; Wu, H.; Shieh, J. 2009. Integration of environmental considerations in quality function deployment by using fuzzy logic. Expert Systems with Applications 36: 7148-7156.

Lin, C.S.; Binns, M.R. 1988. A superiority measure of cultivar performance for cultivar $\times$ location data. Canadian Journal of Plant Science 68: 193-198.

Mamdani, E.H.; Assilian, S. 1975. An experiment in linguistic synthesis with a fuzzy logic controller. International Journal of Human-Computer Studies 7: 1-13.

Menezes, M.D.; Silva, S.H.G.; Mello, C.R., Owens, P.R.; Curi, N. 2014. Solum depth spatial prediction comparing conventional with knowledge-based digital soil mapping approaches. Scientia Agricola 71: 316-323.
Papadopoulos, A.; Kalivas, D.; Hatzichristos, T. 2011. Decision support system for nitrogen fertilization using fuzzy theory. Computers and Electronics in Agriculture 78: 130-139.

Piterbarg, L.I. 2011. Parameter estimation from small biased samples: fuzzy sets vs statistics. Fuzzy Sets and Systems 170: $1-21$.

Qin, X.S.; Huang, G.H.; Zeng, G.M.; Chakma, A.; Huang, Y.F. 2007. An interval-parameter fuzzy nonlinear optimization model for stream water quality management under uncertainty. European Journal of Operational Research 180: 1331-1357.

Simões, M.G.; Shaw, I.S. 2011. Control and Modeling = Controle e Modelagem Fuzzy. Blucher, São Paulo, SP, Brazil (in Portuguese).

Türksen, I.B. 2007. Meta-linguistic axioms as a foundation for computing with words. Information Sciences 177: 332-359.

Viertl, R. 2011. Statistical Methods for Fuzzy Data. Wiley, New York, NY, USA. 